\title{
Analisa Kelayakan Pasar Dan Lingkungan Pada Pengembangan Wisata Bahari Pelabuhan Muncar Banyuwangi
}

\author{
Estu Handayani ${ }^{1}$,Mohamad Dedi ${ }^{2}$ \\ Sekolah Tinggi Ilmu Komputer PGRI Banyuwangi ${ }^{1,2}$
}

\begin{abstract}
The current condition of the Muncar fish port is different from the condition 10 years ago, where around 2008 the port was famous for its biggest fish catch, namely for lemuru, tonggkol, and kite. At present the number of fish catches has decreased dramatically. This condition affects the economy of fishermen and the community around the port. With this condition, research was carried out on the analysis of market and environmental feasibility in the development of the Muncar fish port in Banyuwangi. The aim is to determine the feasibility of developing marine tourism in the Banyuwangi harbor in terms of market and marketing aspects as well as environmental aspects. The research method uses qualitative and quantitative analysis by analyzing market and marketing aspects as well as environmental aspects and conduct regression test analysis. The results obtained that the development of marine tourism in the port of Muncar is feasible. It is stated from the variable Promotion, Place, Price, and Product significantly influence the feasibility of the port and provide a positive influence on the development of marine tourism in the port of Muncar.
\end{abstract}

Keywords: feasibility, market, and marketing aspects, environmental aspects, qualitative

\section{Pendahuluan}

Banyuwangi merupakan kabupaten yang terletak diujung timur pulau Jawa memiliki posisi geografis dan potensi sumber daya yang luar biasa. Dengan letak yang berbatasan langgsung dengan selat Bali di bagian timur, kabupaten Situbondo dibagian utara, kabupaten Jember dan Bondowoso dibagian barat serta samudra Hindia dibagian selatan Banyuwangi memiliki banyak sekali keistimewaan. Diantaranya merupakan kabupaten terluas di pulau Jawa dengan luas wilayah $5.782,50 \mathrm{~km} 2$. Keistimewaan lainnya adalah kabupaten Banyuwangi memiliki banyak pantai dengan keindahan yang mempesona dan menarik wisatawan untuk datang berkunjung. Hal ini dapat diketahui dari data kunjungan wisatawan yang tiap tahunnya selalu meningkat seperti pada tabel dibawah ini : 
Tabel 1.Data Statistik Kunjungan Objek Wisata Kabupaten Banyuwangi

\begin{tabular}{cccccc}
\hline & 2014 & 2015 & 2016 & 2017 & 2018 \\
\hline WISNUS & 1.464 .948 & 1.926 .179 & 4.022 .449 & 4.832 .999 & 4.939 .934 \\
\hline WISMAN & 30.681 & 46.214 & 77.139 & 98.970 & 99.198 \\
\cline { 5 - 6 } & & &
\end{tabular}

- Sumber : Dinas Kebudayaan dan Pariwisata Banyuwangi, 2018

Tabel 2. Data Statistik Kunjungan Hotel Kabupaten Banyuwangi

\begin{tabular}{cccccc}
\hline & 2014 & 2015 & 2016 & 2017 & 2018 \\
\hline WISNUS & 517.488 & 540.669 & 551.513 & 606.664 & 656.850 \\
\hline WISMAN & 51.767 & 59.597 & 64.102 & 71.271 & 80.469 \\
\cline { 3 - 5 }
\end{tabular}

Sumber : Dinas Kebudayaan dan Pariwisata Banyuwangi, 2018

Berdasarkan tabel data diatas, menunjukkan bahwa Banyuwangi merupakan kabupaten yang potensial dalam pengembangan pariwisata. Wisata bahari merupakan salah satu objek wisata yang dikembangkan di Banyuwangi. Di Banyuwangi terdapat pelabuhan ikan terbesar kedua di Indonesia setelah pelabuhan Bagan Siapi-api yang berada di Sumatera Utara. Pelabuhan Ikan terbesar ini dikelola langsung oleh Dinas Perikanan dan Pangan dengan memberdayakan nelayan dan masyarakat sekitarnya. Tetapi kondisi ini belum menjadikan pelabuhan ikan Muncar sebagai tempat wisata bahari yang dikelola dengan baik. Dengan kondisi seperti ini, diharapkan pelabuhan ikan Muncar dapat dikembangkan menjadi tempat wisata bahari yang dapat meningkatkan pendapatan nelayan dan masyarakat sekitar pelabuhan.

Permasalahan lainnya adalah pelaksanaan kegiatan atau festival yang dilakukan diarea pelabuhan baru sebatas kegiatan yang dilaksanakan berdasarkan even dari Pemerintah Daerah, sehingga kehadiran wiatawan pun hanya banyak dan ramai pada saat kegiatan berlangsung. Seperti kegiatan Petik Laut dan Fish Market yang dihadiri banyak wisatawan baik lokal maupun mancanegara. Kondisi pelabuhan ikan Muncar juga harus diperhatikan dari segi produktifitas tangkapan ikan. Pelabuhan ikan Muncar terkenal dengan tangkapan ikan terbesar untuk ikan lemuru, ikan tongkol dan ikan layang. Tahun 2008-2010, merupakan jaman kejayaan pelabuhan ikan Muncar dalam memperolah tangkapan ikan (P2SKP, 2018). Kondisi ini berubah seiring berjalannya waktu, dimana dalam 10 tahun terakhir, tangkapan ikan di pelabuhan ikan Muncar menjadi menurun drastis 
dibanding jaman kejayaan. Seperti data pada tabel berikut :

Tabel 3. Data Produksi Perjenis Ikan Dalam 10 Tahun Terakhir UPT. P2SKP Muncar Banyuwangi

\begin{tabular}{cccccc}
\hline Tahun & 2008 & 2009 & 2010 & 2011 & 2012 \\
\hline Jenis Ikan & \multicolumn{5}{c}{$\mathrm{Kg}$} \\
\hline Layang & 2.879 .767 & 1.067 .070 & 1.057 .942 & 2.268 .370 & 2.013 .177 \\
\hline Tongkol & 2.692 .408 & 1.032 .177 & 877.130 & 1.106 .027 & 1.617 .584 \\
\hline Lemuru & 27.833 .004 & 28.446 .134 & 17.717 .764 & 1.651 .381 & 2.839 .271 \\
\hline
\end{tabular}

Tabel 3. Data Produksi Perjenis Ikan Dalam 10 Tahun Terakhir UPT. P2SKP Muncar Banyuwangi (Lanjutan)

\begin{tabular}{cccccc}
\hline Tahun & 2013 & 2014 & 2015 & 2016 & 2017 \\
\hline Jenis Ikan & \multicolumn{5}{c}{$\mathrm{Kg}$} \\
\hline Layang & 2.656 .893 & 1.096 .629 & 2.424 .502 & 822.569 & 1.521 .857 \\
\hline Tongkol & 577.938 & 973.356 & 734.093 & 576.360 & 1.460 .711 \\
\hline Lemuru & 4.082 .081 & 8.091 .172 & 10.267 .212 & 7.950 .983 & 54.411
\end{tabular}

Sumber : Data UPT. P2SKP Muncar Banyuwangi 2018

Dari tabel diatas dapat diketahui dari tiga jenis tangkapan ikan terbesar di Pelabuhan ikan Muncar, ikan lemuru yang sangat menurun drastis jumlah tangkapannya dari tahun ketahun. Penurunan jumlah tangkapan ikan sangat mempengaruhi kondisi ekonomi masyarakat nelayan Muncar. Kondisi ini menyebabkan banyak nelayan yang kesulitan untuk memenuhi kebutuhan hidup rumah tangganya. Selain itu, perilaku masyarakat sekitar pelabuhan ikan Muncar dan para pendatang masih memiliki perilaku tidak disiplin. Banyak masyarakat dan nelayan membuang sampah sembarangan sehingga kondisi ini menghasilkan pencemaran terhadap ekosistem laut yang berdampak pada penurunan tangkapan ikannya. Menurut (Ulhasanah and Goto, 2019), pendidikan lingkungan merupakan faktor penting dalam mendisain suatu sisten pengelolaan lingkungan yang baik.

Berdasarkan data wilayah, Kecamatan Muncar memiliki jumlah penduduk terbesar di Kabupaten Banyuwangi sehingga sampah yang dihasilkannya perhari juga sangat besar. Dapat dilihat pada tabel dibawah ini : 
Tabel 4. Jumlah Penduduk Dan Timbunan Sampah, 2015

\begin{tabular}{ccccc}
\hline & Jumlah Penduduk & \multicolumn{3}{c}{ Timbunan Sampah } \\
\hline Kecamatan & Tahun 2016 & Liter/Orang/Hari & M $^{3} /$ Hari & Kg/Hari \\
\hline Muncar & 131.840 & 276.863 & 132 & 92.288 \\
\hline Sumber : Data Masterplan Persampahan Banyuwangi 2015 (DLH)
\end{tabular}

Sumber : Data Masterplan Persampahan Banyuwangi 2015 (DLH)

Jumlah sampah yang dihasilkan oleh kecamatan Muncar, menjadi salah satu permasalahan dalam pengembangan wisata. Banyaknya sampah dan belum adanya pengelolaan sampah yang optimal tidak hanya menyebabkan menurunnya jumlah tangkapan ikan tetapi juga menjadi hambatan untuk pengembangan wisata pelabuhan.

Rumusan masalah dari penelitian ini adalah bagaimana kelayakan pada pengembangan wisata bahari pelabuhan muncar Banyuwangi ditinjau dari aspek pasar dan pemasaran serta aspek lingkungan hidup ?. Sedangkan tujuan analisis kelayakan pengembangan wisata bahari yang dilakukan adalah untuk mengetahui kelayakan pada pengembangan wisata bahari pelabuhan muncar Banyuwangi ditinjau dari aspek pasar dan pemasaran serta aspek lingkungan hidup. Manfaat penelitian yang dilakukan ini diharapkan dapat digunakan sebagai bahan pertimbangan atau masukkan terkait dengan pengembangan wisata bahari pelabuhan ikan Muncar Banyuwangi apakah layak direalisasikan setelah dilakukan analisa segmen pasar dan pemasaran serta segmen lingkungan hidup.

\section{Tinjauan Pustaka}

\subsection{Pariwisata}

Pariwisata menurut UU nomer 10 tahun 2009 adalah berbagai macam kegiatan wisata dan didukung dengan berbagai fasilitas serta layanan yang disediakan oleh masyarakat, pengusaha, pemerintah dan pemerintah daerah. Perkembangan pariwisata dalam suatu wilayah dapat didukung dengan adanya daya tarik wisata yang meliputi keindahan, keunikan serta keanekaragaman kekayaan alam, ragam budaya serta keberagaman kulinernya. Selain dukungan dari daya tarik, produk pariwisata juga harus menonjolkan kemudahan-kemudahan bagi para pengunjungnya. Produk pariwisata harus memiliki sarana prasarana yang menunjang, infrastruktur (sanitasi, air, dan lain-lain), kemudahan menuju lokasi 
pariwisata, terdapat pelayanan umum dan pribadi (Bungin, 2017). Pemasaran pariwisata merupakan faktor kunci dalam mempengaruhi keputusan pelanggan. Dengan adanya pariwisata dapat meningkatkan pertumbuhan dan pemerataan ekonomi, meningkatkan kesejahteraan masyarakat dan timbulnya pembangunan terhadap wilayah tersebut.

\subsection{Kelayakan Bisnis}

Menurut (Husen, 2015), studi kelayakan bisnis merupakan penelitian terhadap rencana bisnis yang tidak hanya menganalisis layak atau tidak layak bisnis dibangun, tetapi juga saat dioperasikan secara rutin dalam rangka pencapaian keuntungan yang maksimal untuk waktu yang tidak ditentukan. Analisa kelayakan bisnis dilakukan untuk mengurangi hambatan dan resiko yang mungkin terjadi dimasa yang akan datang. Menurut (Kasmir and Jakfar, 2017), suatu kegiatan yang melibatkan berbagai sumber daya yang terhimpun dalam suatu organisasi untuk mencapai sasaran tertentu. Kegiatan tersebut dilakukan untuk berbagai bidang, yaitu : (a) Pembangunan fasilitas baru, yaitu kegiatan yang belum pernah ada sebelumnya dan dilakukan penambahan usaha baru. (b) Perbaikan fasilitas yang sudah ada, yaitu kegiatan yang dilakukan untuk melanjutkan usaha yang sudah dilakukan sebelumnya. (c) Penelitian dan pengembangan, yaitu kegiatan peneliti yang dilakukan untuk fenomena yang muncul dimasyarakat, kemudian dikembangkan sesuai dengan tujuan yang diharapkan.

Dalam menjalankan studi kelayakan bisnis menurut (Kasmir and Jakfar, 2017) terdapat beberapa tahapan, yaitu pengumpulan data dan informasi, pengolahan data, analisis data, mengambil keputusan dan memberikan rekomendasi apakah bisnis layak atau tidak untuk dilaksanakan. Proses analisis kelayakan suatu kegiatan atau usaha, sangat diperlukan data dan informasi yang jelas untuk mendukung kemudahan dan keberhasilannya kegiatan yang dilakukan. Studi kelayakan sangat diperlukan oleh pihak-pihak yang berkepentingan seperti pemilik usaha, kreditur, pemerintah, masyarakat luas dan manajemen. Kelayakan suatu usaha hendaknya dilakukan secara benar dan lengkap dengan didukung data dan informasi yang jelas. Dalam pelaksanaan kelayakan suatu usaha, dilakukan tahapan yang terdiri dari berbagai aspek. Aspek-aspek yang diperlukan dalam studi 
kelayakan menurut (Kasmir and Jakfar, 2017) terdiri dari Aspek hukum, Aspek pasar dan pemasaran, Aspek keuangan, Aspek teknis, Aspek manajemen, Aspek ekonomi sosial dan, Aspek lingkungan. Selaras dengan penelitian yang dilakukan (Ramdan and Ihkwana, 2016), dalam pengembangan wisata di kampung Cimareme, Garut menggunakan model analisa kelayakan yaitu aspek pasar, aspek teknik dan manajemen serta finansial dan hasil penelitian adalah kegiatan pengembangan yang layak untuk dilakukan. Pada penelitian ini hanya menggunakan dua aspek, yaitu aspek pasar dan pemasaran serta aspek lingkungan, dengan uraian yaitu :

a. Aspek pasar dan pemasaran

Dalam menentukan kelanjutan suatu usaha, munurut (Kasmir and Jakfar, 2017) seorang pemasar harus mengetahui terlebih dahulu pasar yang akan dimasukinya, yaitu ada tidaknya pasar, seberapa besar pasar yang ada, bagaimana potensi pasar yang ada dan tingkat persaingan yang ada. Analisa aspek pasar bertujuan untuk mengetahui seberapa besar luas pasar, pertumbuhan permintaan serta market share dari produk yang ditawarkan sehingga diperoleh segmentasi yang tepat sasaran. Menurut (Laksana, 2019) segmentasi pasar dapat dikelompokkan menjadi beberapa segmen, yaitu: segmentasi geografis, segmentasi demografis, segmentasi psikografis dan segmentasi perilaku. Untuk menentukan besarnya potensi pasar yang ada dalam pengembangan wisata bahari pelabuhan muncar, maka perlu dilakukan riset pasar baik dengan terjun langsung kelapangan ataupun dengan cara mengumpulkan data dari berbagai sumber. Setelah dilakukan aspek pesar selanjutnya dilakukan analisa mengenai aspek pemasaran yang meliputi produk, harga, tempat dan promosi. Hal ini seperti yang diuraikan pada penelitian (Gunawati and Sudarwati, 2017) bahwa unsur utama dalam pemasaran terdiri dari segmentasi pasar, targeting dan positioning.

b. Aspek Lingkungan Hidup

Aspek lingkungan hidup merupakan salah satu aspek penting yang harus dikaji sebelum melakukan analisa kelayakan suatu usaha. Kajian lingkungan hidup ini meliputi dampak negatif dan dampak positif dari kegiatan yang akan dilakukan. Selaras dengan penelitian yang dilakukan oleh (Amrulloh and Mawardi, 2018) dimana Penelitian tersebut betujuan menganalisis tentang kelayakan kawasan UB 
Forest sebagai destinasi wisata berbasis lingkungan sebagai penunjang kegiatan ekowisata. Dalam proses menganalisa suatu kelayakan dalam kegiatan atau usaha juga perlu dilakukan terlebih dahulu studi mengenai dampak lingkungan yang akan terjadi saat ini atau masa yang akan datang. Hal ini juga dinyatakan pada penelitian yang dilakukan oleh (Gunawati and Sudarwati, 2017) mengenai studi tentang dampak lingkungan terhadap kegiatan atau usaha bisnis yang akan dijalankan. Studi AMDAL diperlukan dalam suatu kegiatan pelabuhan berdasarkan undang-undang dan untuk menjaga kualitas lingkungan agar tidak rusak dengan adanya kegiatan di suatu tempat. Peraturan Pemerintah mengenai pengertian analisis dampak lingkungan tercantum pada PP No.27 tahun 1999 Pasal 1, yaitu teknik dalam menganalisis apakah proyek yang akan dijalankan akan mencemarkan lingkungan atau tidak dan alternatif tindakan pencegahannya. Fungsi dilakukannya AMDAL salah satunya untuk memberikan rekomendasi terhadap pengambilan keputusan dan kelayakan lingkungan hidup dari kegiatan atau usaha yang akan dilaksanakan. Dampak negatif yang mungkin akan timbul jika tidak dilakukan AMDAL, yaitu : pengaruh terhadap tanah dan kehutanan, air, udara dan manusia Menurut (Yakin, 2017) dalam mekanisme menyusunan AMDAL, dikenal beberapa dokumen yang harus dipenuhi, yaitu dokumen analisis dampak lingkungan (ANDAL), dokumen rencana pengelolaan lingkungan (RKL) dan dokumen rencana pemantauan lingkungan (RPL). Analisis dampak lingkungan perlu dilakukan guna menelaah dan mencermati terhadap kegiatan yang dilakukan suatu usaha. Untuk mengetahui apakah kegiatan yang dilaksanakan dapat berpotensi terhadap munculnya dampak lingkungan dan juga dapat digunakan sebagai sumber penting dalam pengambilan keputusan terkait izin suatu kegiatan atau usaha yang akan dijalankan. Kajian AMDAL dapat dilakukan dan berkordinasi dengan dinas yang terkait dengan lingkungan hidup, pihak terkait dengan usaha atau kegiatan yang dilakukan maupun bekerja sama dengan lembaga masyarakat atau lembaga non pemerintahan. Menurut (Muda, 2016) dalam penelitiannya menyebutkan perlu dilakukan identifikasi dan evaluasi terhadap perusahaan atau badan usaha yang sudah memiliki dokumen lingkungan, dengan melibatkan masyarakat dalam pengelolaan lingkungan serta adanya pengawasan dari pemerintah daerah mengenai hal ini 


\section{Metode Penelitian}

Metode analisa data yang digunakan pada penelitian ini adalah uji validitas dan reliabilitas. Uji validitas dilakukan untuk mengetahui kuesioner yang dibuat dapat diukur dan untuk uji reliabilitas menunjukkan bahwa kuesioner yang dibuat adalah konsisten apabila digunakan untuk mengukur gejala yang sama sehingga dapat dihasilkan data yang valid. Untuk mengetahui bobot rata-rata jawaban dari kuesioner maka digunakan analisis deskriptif menggunakan alat ukur mean terhadap masing-masing pernyataan pada variabel. Analisa regresi digunakan pada penelitian ini untuk menguji apakah promosi, tempat, harga, produk mempengaruhi kelayakan dari pelabuhan. Sedangkan untuk mengetahui seberapa besar variabel bebas mempengaruhi variabel terikat, maka perlu diketahui nilai koefisien determinasi atau nilai R2. Selain itu juga dilakukan uji F untuk mengetahui apakah variabel bebas secara bersama-sama berpengaruh signifikan terhadap variabel terikat. Penelitian ini juga melakukan uji normalitas dimana normal probability plot digunakan untuk pendeteksian normalitas residua.

Sumber data terdiri dari data primer dan data sekunder. Data primer yang dikumpulkan berupa kejadian atau kegiatan, hasil pengujian, opini orang atau subjek yang dituju. Metode yang digunakan dalam pengumpulan data primer adalah metode survey dan metode observasi. Sumber data sekunder diperoleh secara langsung melalui media perantara dalam bentuk catatan atau laporan yang tersusun dalam bentuk arsip atau data yang dipublikasi. Seperti data yang dikeluarkan BPS Banyuwangi, Dinas Perikanan dan Pangan dan sumber-sumber lainnya.

Sampel penelitian ini dilakukan menggunakan simple random sampling yaitu pengambilan sampel dari populasi yang dilakukan secara acak tanpa memperhatikan strata yang ada. Seperti yang dilakukan oleh (Simanjuntak, Patana and Hartini, 2016) pada pengambilan sampel pegunjung dilakukan berdasarkan kriteria usia. Menurut (Susanti, Halin and Kurniawan, 2018) mengatakan bahwa instrumen penelitian yang dilakukan dalam bentuk kuesioner harus memenuhi persyaratan uji validasi dan uji reliabilitas. 


\section{Hasil Dan Pembahasan}

\subsection{Aspek Pasar dan Pemasaran}

Lokasi penelitian dilakukan di Pelabuhan Muncar dan lingkungan sekitar pelabuhan. Waktu penelitian dilaksanakan pada bulan April sampai bulan Juli 2019. Objek dari penelitian ini adalah kelayakan pelabuhan muncar jika dijadikan sebagai tempat wisata bahari ditinjau dari aspek pasar - pemasaran dan aspek lingkungan. Metode survei dan observasi yang dilakukan dalam penelitian ini yaitu dengan mengumpulkan data menggunakan pertanyaan baik secara lisan maupun tulisan kepada masyarakat sekitar pelabuhan Muncar untuk menggali data yang diperlukan. Selain kepada masyarakat sekitar, pengumpulan data juga diperoleh dari dinas-dinas terkait, seperti dinas Kebudayaan dan Pariwisata, dinas Linkungan Hidup, Badan Penanaman Modal, Dinas Perikanan dan Pangan, Badan Pusat Statistik, UPT Pelabuhan Perikanan Muncar, dan beberapa desa yang terletak dekat dengan pusat penelitian, yaitu desa Tembokrejo, Kedungrejo dan Kedungringin. Sasaran dari populasi penelitian adalah masyarakat sekitar pelabuhan Muncar (desa Tembokrejo, Kedungrejo dan Kedungringin), nelayan, wisatawan dan masyarakat yang mengetahui keberadaan pelabuhan ikan Muncar dengan rentang usia 15 sampai usia diatas 46 tahun. Proses pengambilan sampel ini selaras dengan penelitian yang dilakukan (Wahyudi, 2013) dimana sumber data yang digunakan meliputi data primer yang diperoleh langsung dari responden yaitu konsumen yang melakukan pembelian. Dalam memperoleh data mengenai tanggapan responden dalam menentukan segmentasi pasar dilakukan berdasarkan demografi.

Penilaian pada penelitian ini dilakukan berdasarkan kuesioner yang disebar kepada masyarakat pelabuhan Muncar dan sekitarnya. Dalam penelitian ini menggunakan metode self administrated survey, dimana responden diminta peneliti untuk mengisi sendiri kuesioner yang diberikan. Untuk menentukan jumlah sampel penelitian digunakan rumus Slovin. Error tolerance pada penelitian ini adalah e = $10 \%$ atau 0.1 dari populasi penelitian. Jumlah populasi dalam penelitian ini sebesar 50.377 jiwa. Data diperoleh dari jumlah penduduk (desa Tembokrejo, Kedungrejo dan Kedungringin) dikurangi usia non responden (usia 0 - 14 tahun). (BPS, 2018). Sampel responden penelitian ini sebanyak 102 orang. 
Kuesioner dilakukan untuk mengetahui segmentasi pasar yang dilihat berdasarkan sekmentasi demografis dan segmentasi perilaku. Segmentasi pasar dilakukan untuk mengetahui keinginan dan kebutuhan dari nelayan dan masyarakat sekitar pelabuhan jika pelabuhan Muncar dikembangkan menjadi tempat wisata bahari. Segmentasi pasar yang dilakukan berdasarkan demografis meliputi usia responden, jenis kelamin, pendidikan dan jenis pekerjaan. Sedangkan sekmentasi pasar untuk mengetahui sikap atau tanggapan responden terhadap dilakukan menggunakan segmentasi perilaku. Hasil pengamatan berdasarkan faktor demografis diperoleh data dari 102 responen yang menjadi objek penelitian, sebagian besar resonden berjenis kelamin laki-laki sebanyak 70 orang atau sebesar $68,63 \%$, sisanya adalah perempuan sebanyak 32 orang atau sebesar 31,37\%. Sedangkan usia resonden terbanyak adalah diusia 36 - 45 tahun atau sebesar 44,12\%. Tingkat pendidikan responden mayoritas adalah lulusan SLTA sebanyak 39 orang atau sebesar38,24\%. Untuk jenis pekerjaan responden mayoritas adalah wirausaha sebesar 36 orang atau sebesar 53, $29 \%$.

Sedangkan hasil pengamatan untuk segmentasi perilaku dapat dilihat pada tabel dibawah ini :

\section{Tabel 5. Perilaku Responden}

\begin{tabular}{clcc}
\hline No. & \multicolumn{1}{c}{ Pertanyaan } & Ya & Tidak \\
\hline 1. & Apakah anda merasa nyaman dengan kondisi pelabuhan saat ini? & 87 & 13 \\
\hline 2. & Apakah masyarakat Muncar membutuhkan tempat wisata ? & 102 & 0 \\
\hline 3. & Apakah tempat wisata yang dibutuhkan adalah wisata bahari ? & 91 & 11 \\
\hline 4. & Jika Pelabuhan Muncar dijadikan tempat wisata bahari, apakah layak & 95 & 7 \\
& menurut anda ? & & \\
\hline 5. & $\begin{array}{l}\text { Apakah kegiatan anda akan terganggu jika pelabuhan Muncar } \\
\text { menjadi tempat wisata bahari ? }\end{array}$ & & 92 \\
\hline 6. & $\begin{array}{l}\text { Apakah kegiatan anda akan terganggu jika pelabuhan Muncar ramai } \\
\text { dikunjungi wisatawan? }\end{array}$
\end{tabular}

Dari paparan tabel 5 dapat diketahui bahwa masyarakat pelabuhan ikan Muncar secara umum membutuhkan tempat wisata dan tidak terganggu dengan adanya wisata baru. Hal ini dapat diketahui dari hasil pengamatan pada segmentasi perilaku bahwa rata-rata responden menjawab "Ya" atau lebih dari 90 orang dari 
102 jumlah responden. Dan yang menjawab tidak terganggunya kegiatan masyarakat jika pelabuhan ikan Muncar dijadikan tempat wisata juga rata-rata diatas 90 orang dari 102 jumlah responden.

Berdasarkan kuesioner yang dilakukan terhadap masyarakat sekitar pelabuhan Muncar (desa Tembokrejo, Kedungrejo dan Kedungringin), nelayan, wisatawan dan masyarakat yang mengetahui keberadaan pelabuhan ikan Muncar, maka diketahui bahwa sekmentasi pasar yang dilakukan sangat membantu. Dimana dapat diketahui keinginan serta kebutuhan dari masyarakat sekitar pelabuhan ikan Muncar, nelayan dan wisatawan jika pelabuhan ikan Muncar akan dijadikan tempat wisata bahari.

Aspek pemasaran dalam analisis kelayakan pada pengembangan wisata bahari pelabuhan Muncar menggunakan bauran pemasaran, yaitu promosi, tempat, harga dan produk. Ditambah satu analisa lingkungan hidup untuk mengetahui pengaruh pariwisata terhadap lingkungan pelabuhan. Analisis yang dilakukan adalah dengan mengunakan survey internal untuk menentukan layak atau tidaknya pengembangan wisata bahari pelabuhan Muncar. Penilaian responden terhadap aspek pemasaran dan lingkungan hidup dilakukan dengan menggunakan skala Likert, dimana semakin tinggi nilai survey berarti semakin tinggi pengaruh terhadap nilai yang dihasilkan.

Uji validitas yang dilakukan mengunakan tingkat kepercayaan 95\% atau alpha 0,05 , dimana $\mathrm{df}=\mathrm{n}-2$. Nilai $\mathrm{n}$ dalam penelitian ini yaitu 102 , sehingga $\mathrm{df}=$ 100 dan rtabel adalah 0,195. Hasil uji validitas berdasarkan kuesioner yang disebar kepada masyarakat sekitar pelabuhan Muncar (desa Tembokrejo, Kedungrejo dan Kedungringin), nelayan, wisatawan dan masyarakat yang mengetahui keberadaan pelabuhan Muncar dinyatakan valid, diketahui dari nilai pearson corelation (nilai koefisien korelasi) atau rhitung adalah lebih besar dari 0,195. Dapat diartikan bahwa dimensi-dimensi pada variabel promosi, tempat, harga, produk dan kelayakan pelabuhan dinyatakan valid. Hal ini selaras dengan penelitian yang dilakukan oleh (Handayani and Dedi, 2017) menyatakan bahwa dengan kegiatan promosi mengenai pelabuhan ikan Muncar memberi pengaruh positif terhadap peningkatan jumlah kunjungan wisatawan. Sehingga dapat dikatakan bahwa 
kuesioner yang digunakan pada penelitian ini layak dipakai sebagai alat peneliti. Untuk uji reliabilitas, diperoleh nilai Cronbach Alpha masing-masing variabel lebih besar dari 0,6 sehingga dapat disimpulkan bahwa hasil uji adalah reliabel atau konsisten.

Uji normalitas dilakukan pada penelitian ini, dimana jika terdapat titik-titik yang terkumpul disekitar garis lurus maka disimpulkan bahwa residual regresi berdistribusi normal. Hasil uji normalitas residual dengan normal probability plot dan diperkuat dengan uji kolmogorov smirnov. Regresi berdistribusi normal jika nilai signifikan $>0.05(\alpha=5 \%)$ pada uji kolmogorov smirnov.

Tabel 6. Hasil Uji Normalitas

One-Sample Kolmogorov-Smirnov Test

\begin{tabular}{|c|c|c|}
\hline \multicolumn{3}{|c|}{ Unstandardized Residual } \\
\hline $\mathrm{N}$ & & 102 \\
\hline \multirow[t]{3}{*}{ Normal Parameters ${ }^{\mathrm{a}, \mathrm{b}}$} & Mean &, 0000000 \\
\hline & Std. Deviation & , 13699599 \\
\hline & Absolute &, 048 \\
\hline \multirow[t]{2}{*}{ Most Extreme Differences } & Positive & ,048 \\
\hline & Negative &,- 046 \\
\hline Test Statistic & & ,048 \\
\hline Asymp. Sig. (2-tailed) & & $200^{\mathrm{c}, \mathrm{d}}$ \\
\hline
\end{tabular}

Hasil pengujian One-Simple kolmogorov smirnov test diperoleh nilai signifikan 0,200 yang artinya nilai signifikan lebih besar dari $0.05(\alpha=5 \%)$ berarti regresi berdistribusi normal.

Tabel 7. Hasil Pengujian Analisis Koefisien Determinasi Model Summaryb

\begin{tabular}{ccccc}
\hline Model & $\mathrm{R}$ & R Square & $\begin{array}{c}\text { Adjusted R } \\
\text { Square }\end{array}$ & $\begin{array}{c}\text { Std. Error of the } \\
\text { Estimate }\end{array}$ \\
\hline 1 &, $975^{\mathrm{a}}$ &, 951 &, 949 &, 14052 \\
\hline
\end{tabular}

a. Predictors: (Constant), Promosi, Tempat, Harga, Produk, Lingkungan Hidup

b. Dependent Variable: Kelayakan Pelabuhan

Sumber : Data penelitian diolah SPSS 25, (2019)

Hasil koefisien determinasi atau $\mathrm{R}$ adalah 0,975 atau $97,5 \%$ berarti terdapat korelasi antara variabel bebas (promosi, tempat, harga, produk, lingkungan hidup) 
terhadap variabel kelayakan pelabuhan sebesar 0,831. Nilai yang diperoleh ini menunjukkan hubungan yang erat karena nilai mendekati 1. Untuk nilai R Square (R2) diperoleh 0,951 berarti presentase sumbangan pengaruh variabel bebas (promosi, tempat, harga, produk, lingkungan hidup) terhadap variabel terikat kelayakan pelabuhan sebesar 95,1\%. Sedang sisanya 4,9\% dipengaruhi oleh variabel lain yang tidak dimasukkan dalam penelitian ini.

Untuk uji Normalitas dengan metode grafik dapat dilihat pada gambar dibawah ini:

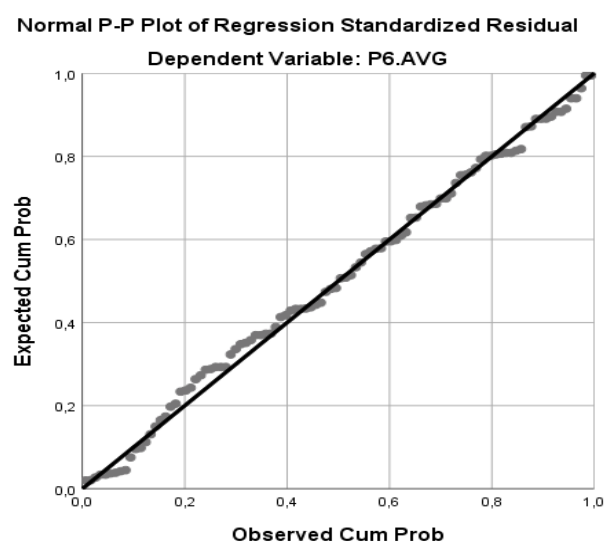

Grf : Normal P-P Plot

Sumber : Data penelitian diolah SPSS 25, (2019)

Setelah dilakukan pengujian koefisien determinasi selanjutnya dilakukan uji F atau uji ANOVA seperti pada tabel berikut :

Tabel 8. Hasil Uji Simultan (Uji F) ANOVAa

\begin{tabular}{lccccc}
\hline Model & Sum of Squares & df & Mean Square & F & Sig. \\
\hline Regression & 37,071 & 5 & 7,414 & 375,487 &, $000^{\mathrm{b}}$ \\
Residual & 1,896 & 96 &, 020 & & \\
Total & 38,966 & 101 & & &
\end{tabular}

a. Dependent Variable: Kelayakan Pelabuhan

b. Predictors: (Constant), Promosi, Tempat, Harga, Produk, Lingkungan Hidup

Sumber : Data penelitian diolah SPSS 25, (2019)

Berdasarkan hasil uji diperoleh $\mathrm{F}$ hitung sebesar 375,487 dengan tingkat signifikan sebesar 0,000. Dikarenakan tingkat signifikan jauh lebih kecil dari $\alpha=$ 0,05 , berarti pengujian yang dilakukan adalah signifikan, yaitu dengan resiko 
kekeliruan 5\%. Dari hasil uji ini menunjukkan bahwa elemen Promosi, Tempat, Harga, Produk dan Lingkungan Hidup secara simultan berpengaruh terhadap kelayakan pelabuhan.

\subsection{Aspek Lingkungan Hidup}

Analisa aspek lingkungan dalam penelitian ini sangat diperlukan sekali, dimana terjadinya perubahan lingkungan yang sangat besar akibat adanya kegiatan yang ada dipelabuhan Muncar. Sasaran dari tujuan pelaksanaan analisis segmen lingkungan hidup terhadap pengembangan wisata bahari pelabuhan Muncar adalah untuk menjaga dari segala bentuk kerusakan, pencemaran atau kegiatan yang merugikan kelestarian lingkungan hidup pelabuhan Muncar serta lingkungan sekitar pelabuhan.

Untuk mengantisipasi terjadinya pencemaran lingkungan, maka suatu kegiatan pelabuhan diwajibkan membuat AMDAL sesuai dengan Undang-Undang Nomer 32 tahun 2009 tentang perlindungan dan pengelolaan Lingkungan Hidup yang menyebutkan bahwa "Setiap usaha dan/atau kegiatan yang wajib memiliki AMDAL atau UKL-UPL wajib memiliki izin lingkungan”.

Pelabuhan ikan Muncar telah melakukan studi AMDAL pada tahun 2010 dan dilakukan oleh CV. Ahmad \& Associates, Environmental Consultants, Surabaya. Berdasarkan hasil dan prakiraan dampak dan evaluasi yang dilakukan pada kegiatan proyek pelabuhan perikanan pantai Muncar tahun 2010, diperoleh hasil bahwa kegiatan yang menimbulkan dampak besar dan penting perlu dilakukan pengelolaan dan pemantauan terhadap lingkungan hidupnya. Dan pada proses AMDAL pada pelabuhan perikanan pantai Muncar tidak ada dikarenakan lokasi, bahan/baku proses dan teknologi yang digunakan sudah dianalisa dalam studi kelayakan sebelum dilakukannya proses AMDAL tahun 2010. Hasil evaluasi selanjutnya dituangan dalam dokumen Rencana Pengelolaan Lingkungan (RKL) dan Rencana Pemantauan Lingkungan (RPL).

Berdasarkan studi kelayakan yang sudah dilakukan Dinas pelabuhan perikanan pantai Muncar mendapatkan rekomendasi dari tim studi kelayakan lingkungan dengan pemaparan diantaranya mengenai : (a) Studi AMDAL 
pelabuhan perikanan pantai Muncar dinyatakan layak dengan catatan perlu dilakukan kembali upaya dan kegiatan yang berhubungan dengan pengelolaaan lingkungan. (b) Proses pencegahan dampak lingkungan sedini mungkin yang berkaitan dengan aspek sosial dan kemasyarakatan, perlu dilakukan pertemuan secara periodik dengan masyarakat nelayan. (c) Dilaksanakan RKL dan RPL beserta pelaporannya sesuai dengan Kepmen LH No.45 tahun 2015 tentang pedoman penyusunan laporan pelaksanaan RKL dan RPL. (d) Dalam pelaksanaan RKL dan RPL, apabila ditemukan dampak-dampak yang menyimpang dari ketentuan, maka diperlukan perubahan dokumen RKL dan RPL. (d) Studi AMDAL perlu dilakukan peninjauan per periode.

Uji kelayakan lingkungan hidup yang dilakukan peneliti terhadap pelabuhan Muncar adalah berdasarkan hasil kuesioner yang diberikan kepada responden. Nilai yang diperoleh adalah valid untuk semua dimensi pernyataan, seperti pada tabel dibawah ini :

Tabel 9. Hasil Uji Validitas terhadap Variabel Lingkungan Hidup

\begin{tabular}{|c|c|c|c|}
\hline Dimensi & Pearson Corelation & rtabel & Status \\
\hline 1.Banyak sampah dilokasi pelabuhan & 0.625 & 0.195 & Valid \\
\hline 2.Bau menyengat & 0.595 & 0.195 & Valid \\
\hline 3.Tersedianya air bersih pada musim kemarau & 0.692 & 0.195 & Valid \\
\hline 4.Kondisi air bersih tidak berbau & 0.605 & 0.195 & Valid \\
\hline 5.Kondisi air bersih jernih & 0.740 & 0.195 & Valid \\
\hline $\begin{array}{l}\text { 6.Ada keterlibatan pemerintah terhadap } \\
\text { pengelolaan lingkungan, mis. : dalam } \\
\text { pengolahan sampah, dll }\end{array}$ & 0.418 & 0.195 & Valid \\
\hline
\end{tabular}

Sedangkan untuk untuk pengujian reliabilitas variabel lingkungan hidup memiliki nilai cronbach'c alpha lebih besar dari 0,6, yaitu 0,650 sehingga dapat disimpulkan bahwa hasil uji adalah reliabel atau konsisten.

Tabel 10. Hasil Uji Reliabilitas terhadap Variabel Lingkungan Hidup

\begin{tabular}{cccc}
\hline Variabel & $\begin{array}{c}\text { Cronbach'c Alpha } \\
\text { Hitung }\end{array}$ & $\begin{array}{c}\text { Cronbach'c Alpha } \\
\text { Standard }\end{array}$ & Hasil \\
\hline Lingkungan hidup & 0,650 & 0,6 & Reliabel \\
\hline Sumber : Data Penelitian diolah SPSS 25, (2019) & &
\end{tabular}


Sekmen lingkungan hidup juga dilakukan UPT P2SKP Muncar Banyuwangi dengan bekerja sama dengan desa Tembokrejo untuk mengambil sampah pelabuhan. Dan selanjutnya sampah pelabuhan tersebut dikelola secara profesional melalui TPS yang ada di desa Tembokrejo.

Dalam rangka program penyelamatan lingkungan hidup, Muncar menjadi salah satu wilayah yang direkomendasikan untuk menjalankan kemitraan dengan konsep Stopping The On Ocean Plastic (STOP). Kemitraan ini dilaksanakan antara Systemiq bekerjasama dengan Badan Usaha Milik Daerah (BUMdes). Dimana Systemiq ini merupakan organisasi lingkungan hidup yang berkedudukan di Jerman dan Inggris. Kegiatan kerjasama ini dilakukan untuk pengelolaan sampah yang berkelanjutan serta memiliki nilai ekonomis bagi masyarakat, khususnya masyarakat Muncar. Program Systemiq dijalankan dari tahun 2018 sampai 2020.

\section{Kesimpulan}

Berdasarkan analisa kelayakan yang dilakukan terhadap pengembangan wisata bahari pelabuhan Muncar dilihat dari :

a. Aspek pasar dan pemasaran

Promosi, Tempat, Harga dan Produk berpengaruh signifikan terhadap kelayakan pelabuhan ikan Muncar dan memberikan pengaruh positif terhadap pengembangan wisata bahari pelabuhan ikan Muncar. Sehingga dapat dikatakan bahwa pengembangan wisata bahari pelabuhan Muncar adalah layak dilakukan.

b. Aspek Lingkungan Hidup

Lingkungan hidup berpengaruh signifikan terhadap kelayakan pelabuhan ikan Muncar dan memberikan pengaruh positif terhadap pengembangan wisata bahari pelabuhan ikan Muncar. Untuk kondisi lingkungan hidup pelabuhan Muncar, uji kelayakan tidak dilakukan kembali karena pelabuhan perikanan pantai Muncar sudah dianalisa studi kelayakannya sebelum dilakukannya proses AMDAL tahun 2010. Hasil evaluasi selanjutnya dituangkan dalam dokumen Rencana Pengelolaan Lingkungan (RKL) dan Rencana Pemantauan Lingkungan (RPL).

Berdasarkan analisis kelayakan yang telah dilakukan, terdapat beberapa hal yang perlu diperhatikan dalam merealisasikan pengembangan wisata bahari 
pelabuhan ikan Muncar diantaranya : (a) Melakukan koordinasi kepada berbagai pihak dalam upaya membuat pelabuhan ikan Muncar sebagai tempat wisata bahari dan meningkatkan promosi terhadap kegiatan-kegiataan yang akan diadakan di area pelabuhan ikan Muncar. (b) Perlu dilakukan analisa lebih mendalam mencakup aspek-aspek lainnya, seperti aspek sosial, ekonomi dan lainnya. (c) UPT Pelabuhan Perikanan Muncar menbuat aturan terhadap tindakan yang melangar pencemaran terhadap lingkungan hidup khususnya lingkungan pelabuhan ikan Muncar.

\section{Ucapan Terima Kasih}

Penulis mengucapkan terima kasih kepada Kementerian Riset, Teknologi, Dan Pendidikan Tinggi (Ristek Dikti) untuk pemberian dana hibah Penelitian Dosen Pemula dan dukungannya sehingga dapat terlaksananya penelitian ini

\section{DAFTAR PUSTAKA}

Amrulloh, H. A. and Mawardi, M. K. (2018) 'Analisa Kelayakan Ub Forest Sebagai Destinasi Wisata Berbasis Eco Tourism', Jurnal Administrasi Bisnis, 61(1), pp. 80-89.

BPS (2018) Kecamatan Muncar Dalam Angka. Banyuwangi: BPS Kabupaten Banyuwangi.

Bungin, B. (2017) Komunikasi Pariwiata, (Tourism Communication) Pemasaran dan Brand Destinasi. Jakarta: Kencana.

Gunawati, U. and Sudarwati, W. (2017) 'Analisis Studi Kelayakan Usaha Bisnis Cassava Chips Di Perumahan Mardani Raya', Jurnal Integrasi Sistem Industri, 4(1), pp. 35-44.

Handayani, E. and Dedi, M. (2017) 'Pengaruh Promosi Wisata Bahari Dan Kualitas Pelayanan Terhadap Peningkatan Jumlah Kunjungan Wisatawan Di Pelabuhan Muncar Banyuwangi', Jurnal Wira Ekonomi Mikroskil, 7(2), pp. $151-159$.

Husen, U. (2015) Studi Kelayakan Bisnis, Teknik Menganalisis Kelayakan Rencana Bisnis Secara Komprehensif. Jakarta: PT. Gramedia Pustaka Utama. 
Kasmir and Jakfar (2017) Studi Kelayakan Bisnis. Depok: Kencana.

Laksana, M. F. (2019) Praktis Memahami Manajemen Pemasaran. Jakarta: Khalifah Mediatama.

Muda, A. (2016) 'Analisis Mengenai Dampak Lingkungan Paket Pelebaran Jalan RTA Milono Palangkaraya', Media Ilmiah Teknik Lingkungan, 1(1), pp. 15.

P2SKP (2018) Laporan Tahunan Unit Pelaksana Teknis Pelabuhan dan Pengelolaan Sumberdaya Kelautan dan Perikanan, Muncar Banyuwangi. Banyuwangi.

Ramdan, R. M. and Ihkwana, A. (2016) 'Analisa Kelayakan Pengembangan Wisata di Desa . Cimareme', pp. 101-110.

Simanjuntak, C. R., Patana, P. and Hartini, K. (2016) 'Analisis Kelayakan dan SWOT Objek Wisata Pemandian Alam Taman Rekreasi Gotong Royong Indah di Desa Hulu, Kecamatan Pancurbatu, kabupaten Deli Serdang, Provinsi Sumatera Utara', Peronema Forestry Science Journal, 5(1), pp. $176-183$

Susanti, N., Halin, H. and Kurniawan, M. (2018) 'Pengaruh Bauran Pemasaran (4P) Terhadap Keputusan Pembelian Perumahan PT. Berlian Bersaudara Propertindo (Studi Kasus Perumahan Taman Arizona 1 Taman Arizona 2 dan Taman Arizona 3 di Talang Jambi Palembang)', Jurnal Ekonomi Global Masa Kini, 8(1), pp. 43-49.

Ulhasanah, N. and Goto, N. (2019) 'Apakah Pendidikan Lingkungan Merupakan Faktor Utama Pembentuk Perilaku Lingkungan pada Masyarakat di Negara Berkembang?', Jurnal Dampak, 16(1), pp. 31-41. doi: 10.25077/dampak.16.1.31-41.2019.

Wahyudi, H. (2013) 'Segmentasi Pasar Berdasarkan Demografi Terhadap Produk Mobil Nissan Pada PT. Wahana Wirawan Manado', Jurnal EMBA, 1(3), pp. $302-310$.

Yakin, S. K. (2017) 'Analisis Mengenai Dampak Lingkungan (AMDAL) Sebagai Instrumen Pencegahan Pencemaran Dan Perusakan Lingkungan', Badamai Law Journal, 2(1), pp. 113-132. 